\title{
Book Review The Truth About Mohammed
}

Book Review of

The Truth About Mohammed Founders of the World's Most Intolerant Religion, By RobertSpencer (2006), Regnory Publishing, Washington, DC, USA, pp. 224.

In these days of militant Islam, The Truth About Mohammed is required reading. Having been a student of Islam for many years, I find this book to be an accurate, courageous and unimpeachable description of how Mohammed founded Islam.

Mohammed began as a confused Christian apostate and apparently had, as best one can reluctantly say about him, a divine revelation by the angel Gabriel which justifies his claim to be prophet and allow him to appropriate a "religion" claim. However, more obvious is the fact that the angel Gabriel was replaced by satan masquerading as an "angel of light" (2 Corinthians 11:14), such that Mohammed continued not as prophet of God but a prophet of non-being (And, the fostering of non-being is evil). Unable to keep faith with his true religious origins including Gabriel, Mohammed became a power mad, possibly psychotic, destroyer of the transcendentals (The transcendentals are the absolute hallmarks of every true religion). The Truth About Mohammed is true to its title, and the book includes the rationalizations of Muslim leaders to pathologically deny the deplorable relations and transparent utilitarianism of Mohammed once he began to fabricate recitations from the angel Gabriel which became more and more transparently self serving for Mohammed's needs as well as totally at odds with historical divine messages of all religions. It is amazing that Muslims irrationally remain entranced with the disgraceful Mohammed whose actions would be roundly and universally condemned if done by anyone else, especially to Muslims (Truly, the Golden Rule is not used by Mohammed and his followers).

When not in the majority, Muslims hide The Truth About Mohammed. When in the majority, Muslims must promote a mythology (non-being!) of intolerant subordination, psychological feudalism and guiltless destruction of all those who differ. Never more apparent is the overwhelming sense of jealousy and inferiority which can only be overcome by destroying those different ... and for Islam, every difference is a casus belli. The Truth About Mohammed and all Islam is proof that power madness is based on hate which is based on jealousy of those hated. Unable to allow oneself to even consider those different, one must destroy them out of fear of becoming like them even though one is attracted to be like them. "Destroy that which appeals" is Islam's First Commandment. It is an intrinsic inferiority and promotion of non-being rather than acceptance of reality and genuine transcendental existence. This history of Mohammed is appalling and cannot be changed but only tendentiously distorted and analyzed as if it is not, all the while destroying those who offer anything more palatable, more transcendental, more human, more beautiful, more Allah, and more attractive than Islam itself. One is reminded of the 2006 visit of the Pope to Turkey where a Muslim religious leader dimwittingly challenged the Pope in diplomatic style saying as accurately paraphrased: "If you continue to accuse

\author{
Perspective \\ Volume 3 Issue 5 - 2015 \\ Dr. Samuel A Nigro M.D* \\ Retired, Assistant Clinical Professor Psychiatry, Case Western \\ Reserve University School of Medicine, USA \\ *Corresponding author: Dr. Samuel A Nigro M.D, Retired, \\ Assistant Clinical Professor Psychiatry, Case Western Reserve \\ University School of Medicine, 2517 Guilford Road, Cleveland \\ Heights, Ohio 44118, USA, Tel: 216 932-0575; Email: \\ sam@docnigro.com
}

Received: August 19, 2015 | Published: October 7, 2015

us of spreading Islam by sword, we will use it again."

The Truth About Mohammed references the Koran appropriately but does not clarify the Koran -- hopefully another such book (suggested title is The Truth About the Koran) will be forthcoming from Robert Spencer. The Koran is important because it continues the power of Mohammed, even when he is discovered as described. While the history of Mohammed cannot be changed, the Koran can, regardless of protestations to the contrary. The Koran can be re-defined from the Book of Non-Being and The Dead to a transcendental Christian supporting document that it began to be before Mohammed went bad. Mohammed cannot survive critical commentary except for the first portion of his life, but the Koran can survive if all remaining satanic verses are completely expunged. The problem is not just intolerance but the guiltless violence willing to be used as authorized, justified, and rationalized by the Koran. There will never be a fully humanizing Islam until the Koran is sanitized of the remaining satanic verses, i.e., those verses that are anti-transcendental and promote nonbeing. At the beginning, satanic verses were removed. All the others must be likewise expunged. Until that happens, there will never be peace and the Koran will never be as Allah wills until all the press and media begin to challenge Muslims about the Koran.

The following questions need to be asked over and over and over so the Muslim in the street can get the word that he is being manipulated by self-serving Islamic leaders using an untrue Koran because of the self-serving satanic add-ons by Mohammed after he left Mecca. How can that book create such monsters? How can the evil described in The Truth About Mohammed and elsewhere be corrected? How can humanity be helped to live together peacefully with oneness through diversity until the Koran is cleansed? When will the rationalizations cease? When will the pious emotional shrieking end? When will you be strong enough to apologize for your history where appropriate and return to the true Koran and the genuine pre-Medina Mohammed? When will Muslims stop carrying on like guilty damn fools whenever they have to deal with accusations, true or false? Will inferiority ever be overcome until the power madness of the Koran is exposed as satanic? When will it stop? When will Muslims get over the interminable embarrassment of Muslim history and satanic 
verses and finally clean up the Islamic mess? When will you stop shrieking in joy at the killing of people who do not agree with you? Do Muslims have to kill those with whom they disagree? Or do they just merely ignore them waiting for someone else to kill them?

The Truth about Mohammed enables the understanding why Islam is a mindless power mad extravaganza filled with lies, deceit, deceptions, all made "right" by power mad satanic verses in the Koran. Not to doubt is to be a fool.

Unfortunately, as Muslim leaders would have it, to deal with doubt is to declare war on those who criticize -- and the vicious acts of Muslims prove the anti-transcendental and nonbeing nature of the unexpunged Koran itself. One gets the dulling of moral awareness, nightmares instead of pleasant dreams, crying instead of singing, and violence instead of God's love. That voice of God crying in the desert was not Mohammed. 